\title{
Drivers of intrapopulation variation in resource use in a generalist predator, the macaroni penguin
}

\author{
C. Horswill ${ }^{1,2,6, *}$, J. Matthiopoulos ${ }^{2}$, N. Ratcliffe ${ }^{1}$, J. A. Green ${ }^{3}$, P. N. Trathan ${ }^{1}$, \\ R. A. R. McGill ${ }^{4}$, R. A. Phillips ${ }^{1}$, T. C. O'Connell ${ }^{5}$ \\ ${ }^{1}$ British Antarctic Survey, Natural Environment Research Council, High Cross, Cambridge, CB3 0ET, UK \\ ${ }^{2}$ Institute of Biodiversity, Animal Health \& Comparative Medicine, University of Glasgow, Glasgow, G12 8QQ, UK \\ ${ }^{3}$ School of Environmental Sciences, University of Liverpool, Liverpool, L69 3GP, UK \\ ${ }^{4}$ NERC Life Sciences Mass Spectrometry Facility, Scottish Universities Environmental Research Center, East Kilbride, G75 0QF, UK \\ ${ }^{5}$ Department of Archaeology \& Anthropology, University of Cambridge, Cambridge, CB2 3DZ, UK \\ ${ }^{6}$ Present address: British Trust for Ornithology, The Nunnery, Thetford, Norfolk, IP24 2PU, UK
}

\begin{abstract}
Intrapopulation variation in resource use occurs in many populations of generalist predators with important community and evolutionary implications. One of the hypothesised mechanisms for such widespread variation is ecological opportunity, i.e. resource availability determined by intrinsic constraints and extrinsic conditions. In this study, we combined tracking data and stable isotope analysis to examine how breeding constraints and prey conditions influenced intrapopulation variation in resource use in a generalist predator, the macaroni penguin Eudyptes chrysolophus. Isotopic variation was also examined as a function of breeding success, individual traits and individual specialisation. Variation in isotope ratios was greatest across multiple tissue types when birds were able to undertake mid-range foraging trips (i.e. during incubation and pre-moult). This variation was highly consistent between years that spanned a 3 -fold difference in local prey Euphausia superba density, and was also highly consistent at the individual level between 2 years that had similar prey densities. Furthermore, by comparing our results with previous work on the same population, it appeared that a decrease in local prey availability can also increase intrapopulation variation in resource use during periods with more restricted foraging ranges (i.e. during brood-guard and crèche). This study highlights the importance of considering ecological interactions that operate on multiple spatio-temporal scales when examining the drivers of resource use in populations of generalist predators.
\end{abstract}

KEY WORDS: Central-place constraint $\cdot$ Diet $\cdot$ Foraging range $\cdot$ Habitat use $\cdot$ Intrapopulation variation $\cdot$ Individual specialisation $\cdot$ Seabird $\cdot$ Stable isotope analysis

\section{INTRODUCTION}

Intrapopulation variation in resource use is widely reported among natural populations of generalist predators with important implications for community and evolutionary ecology (Hughes et al. 2008, Araújo et al. 2011, Bolnick et al. 2011). By exploiting a different subset of the resources available to a population,

\footnotetext{
*Corresponding author: catrsw@gmail.com
}

individuals may experience different levels of competition, predation and parasitism, and be more vulnerable to climatic fluctuations, as well as changes in prey availability. Consequently, a more comprehensive understanding of the mechanisms that produce individual variation in resource use and the ecological implications of such diversity is required (Araújo et al. 2011, Ceia \& Ramos 2015).

() The authors 2016. Open Access under Creative Commons by Attribution Licence. Use, distribution and reproduction are unrestricted. Authors and original publication must be credited. Publisher: Inter-Research · www.int-res.com 
Ecological opportunity is one of the mechanisms assumed to generate intrapopulation variation in resource use and represents the availability of local resources determined by intrinsic constraints and extrinsic conditions (Araújo et al. 2011). Intrinsic drivers of opportunity include biological constraints that affect an individual's ability to exploit specific prey resources, e.g. sex, experience and foraging range (González-Solís et al. 2000, Weimerskirch et al. 2014, Kernaléguen et al. 2015). In contrast, extrinsic drivers of opportunity reflect conditions that directly affect local prey biomass or availability, e.g. patch size, climate and topography (Herrera et al. 2008, Evangelista et al. 2014). Thus, ecological opportunity can vary on multiple spatial and temporal scales and can also fluctuate independently of the abundance or number of individuals in a population, i.e. it is associated with, but also distinct from, the influence of competition (Araújo et al. 2011).

Quantitative studies that have examined ecological opportunity as a driver of intrapopulation variation in resource use consistently report a positive correlation between opportunity and resource use diversity. The majority of these studies examined ecological opportunity by comparing allopatric or sub-populations that inhabit systems with different extrinsic conditions, such as levels of prey diversity (e.g. Layman et al. 2007, Darimont et al. 2009, Evangelista et al. 2014). However, alternative approaches include a comparison of sympatric species that have different intrinsic constraints restricting foraging range and resource accessibility (Kernaléguen et al. 2015). As yet, few studies have investigated temporal variability in resource use within a population (but see Herrera et al. 2008), and studies examining spatiotemporal variability as a function of intrinsic and extrinsic drivers are largely lacking.

In the marine environment, variability in physical processes can generate large spatial and temporal changes in the distribution and aggregation of prey resources (Pace et al. 1999, Behrenfeld et al. 2006). In addition, marine predators such as seabirds and seals experience intrinsic constraints on foraging ranges imposed by breeding that restrict access to specific resources during the annual cycle. These conditions provide, to some extent, a natural experiment for examining how intrapopulation variation in resource use changes over different temporal and spatial scales. For example, the local biomass of Antarctic krill Euphausia superba at South Georgia can fluctuate several-fold between years (Hewitt et al. 2003, Fielding et al. 2014), and substantially impact the diet and activity budgets of predators that depend on krill as a primary prey resource (Croxall et al. 1999). Macaroni penguins Eudyptes chrysolophus are one of the most important avian consumers of krill in this region (Brooke 2004), and also exhibits limited sexual dimorphism in size (Williams 1995). Consequently, individual penguins from a single colony theoretically have the same foraging opportunities, and recent studies based on stable isotope analysis have indicated that macaroni penguins can display different levels of intrapopulation variation in resource use within the annual cycle (Bearhop et al. 2006, Cherel et al. 2007). However, in both of these studies, small sample sizes precluded reliable identification of distinct groups that exploited different subsets of resources.

We combined tracking data and stable isotope analysis to examine the influence of foraging range, and therefore intrinsic ecological opportunity, on intrapopulation variation in resource use within the annual cycle. In addition, we examined the influence of extrinsic changes in opportunity by comparing isotopic variation among the population across years with a 3fold difference in prey density. Individual consistency in isotope ratios between years, and the relationship between isotopic variation, breeding success and individual traits (sex, body mass and timing of breeding), were also examined using a subset of samples. We predicted that intrapopulation variation among individuals should (1) change in relation to seasonal foraging constraints and be lower during the chickrearing phases (brood-guard and crèche), when foraging ranges and ecological opportunities are reduced; and (2) show some flexibility within different breeding stages if local prey availability changes.

\section{MATERIALS AND METHODS}

\section{Stable isotope samples}

Feather, blood plasma and blood cell samples were collected from breeding macaroni penguins at the Fairy Point colony, Bird Island, South Georgia $\left(54^{\circ} 00^{\prime} \mathrm{S}, 38^{\circ} 03^{\prime} \mathrm{W}\right)$. Opportunistic guano samples were also collected; however, these methods and results are not discussed further in the main text due to limited sample sizes that duplicated the conclusions based on other tissues (see Supplement 1 at www.int-res.com/articles/suppl/m548p233_supp.pdf). We used $\delta^{13} \mathrm{C}$ as a proxy of foraging habitat (France 1995, Cherel \& Hobson 2007) and $\delta^{15} \mathrm{~N}$ as a proxy for the trophic level of prey consumed (Schoeninger \& DeNiro 1984), although the ratios of $\delta^{15} \mathrm{~N}$ can also provide a spatial component in marine systems if the 
complexity of food-chains offshore differs from those inshore. Throughout the text a breeding season is referred to by the year that the chick fledged, and all fieldwork was approved by the British Antarctic Survey Animal Ethics Committee.

\section{Blood samples collected during the 2012 breeding season}

The annual cycle of the macaroni penguin is divided into several phases that each has a different foraging range and set of ecological opportunities (Table 1). Blood samples were collected from breeding birds to reflect different phases of the 2012 annual cycle: the pre-breeding season (by sampling at arrival), the breeding season (which includes incubation, brood-guard and crèche) and the subsequent premoult phase (see Table 2 for sample sizes). Individuals were selected from a random sample of 200 nests distributed throughout the colony that were marked at the start of the breeding season. Samples were taken from the brachial vein (non-heparinised syringe and 23-gauge needle, Microlance; Samour et al. 1983) and

Table 1. Breeding cycle of macaroni penguins at Bird Island, South Georgia, and the direction (+: increase; -: decrease) of body mass change during each phase (adapted from Williams 1995, Barlow \& Croxall 2002, Green et al. 2009). Breeding season includes incubation, brood-guard and crèche phases

\begin{tabular}{|c|c|c|c|c|c|c|}
\hline \multirow[t]{2}{*}{ Month } & \multirow{2}{*}{$\begin{array}{l}\text { Breeding } \\
\text { phase }\end{array}$} & \multirow{2}{*}{$\begin{array}{c}\text { Trip } \\
\text { duration }\end{array}$} & \multicolumn{2}{|c|}{$\longrightarrow$ Male $\longrightarrow$} & \multicolumn{2}{|c|}{ Female } \\
\hline & & & Behaviour & $\begin{array}{l}\text { Body mass } \\
\text { (\% change) }\end{array}$ & Behaviour & $\begin{array}{l}\text { Body mass } \\
\text { (\% change) }\end{array}$ \\
\hline October & \multicolumn{2}{|c|}{ Start of breeding season } & Courts $^{\mathrm{a}}$ & - & Courts $^{\mathrm{a}}$ & - \\
\hline November & Incubation & $10-15 \mathrm{~d}$ & Incubates $^{a}$ & $-(30)$ & Incubates $^{a}$ & - \\
\hline \multirow[t]{2}{*}{ December } & Incubation & $12-14 \mathrm{~d}$ & At sea ${ }^{b}$ & $+(40-50)$ & Incubates $^{\mathrm{a}}$ & $-(40)$ \\
\hline & Incubation & $9-11 \mathrm{~d}$ & Incubates $^{\mathrm{a}}$ & - & At sea ${ }^{b}$ & $+(30)$ \\
\hline January & Brood-guard & $11-12 \mathrm{~h}$ & Brood-guard $^{\mathrm{a}}$ & $-(40-50)$ & Provisions $^{b}$ & $-(20)$ \\
\hline February & Crèche & $11-50 \mathrm{~h}$ & Provisions $^{\mathrm{b}}$ & $+(20)$ & Provisions $^{b}$ & $-(10)$ \\
\hline \multirow[t]{2}{*}{ March } & Pre-moult & $12-14 \mathrm{~d}$ & At sea ${ }^{b}$ & $+(50-70)$ & At sea ${ }^{b}$ & $+(40-60)$ \\
\hline & Moult & $24-25 \mathrm{~d}$ & Moults $^{\mathrm{a}}$ & $-(50)$ & Moults $^{\mathrm{a}}$ & $-(50)$ \\
\hline April & \multicolumn{2}{|c|}{ End of breeding season } & At sea & + & At sea & + \\
\hline
\end{tabular}

Table 2. Stable isotope ratios of different tissues collected from macaroni penguins at Bird Island, South Georgia, by sex and time (year or breeding phase). Values are mean \pm SD. PB: pre-breeding; Inc: incubation; BG: brood-guard (female only); Cr: crèche; PM: pre-moult; $\mathrm{M}$ : male; F: female; -: males fast onshore during brood-guard and therefore were not sampled for stable isotope analysis during this phase

\begin{tabular}{|c|c|c|c|c|c|c|c|c|c|}
\hline \multirow[t]{2}{*}{ Sample } & \multirow[t]{2}{*}{ Year } & \multirow[t]{2}{*}{ Phase } & \multirow[t]{2}{*}{$\mathrm{n}$} & \multicolumn{2}{|c|}{$-\delta^{13} \mathrm{C}$} & \multicolumn{2}{|c|}{$-\delta^{15} \mathrm{~N}-$} & \multicolumn{2}{|c|}{$-\mathrm{C}: \mathrm{N}$ ratio } \\
\hline & & & & M & $\mathrm{F}$ & M & $\mathrm{F}$ & M & $\mathrm{F}$ \\
\hline \multirow[t]{5}{*}{ Feather } & 2001 & PM & 40 & $-21.4 \pm 0.8$ & $-21.4 \pm 0.7$ & $9.5 \pm 0.6$ & $9.3 \pm 0.7$ & $3.7 \pm 0.0$ & $3.7 \pm 0.0$ \\
\hline & 2002 & PM & 40 & $-19.7 \pm 1.2$ & $-19.9 \pm 1.0$ & $11.5 \pm 0.5$ & $10.9 \pm 0.7$ & $3.8 \pm 0.0$ & $3.8 \pm 0.0$ \\
\hline & 2003 & PM & 33 & $-20.9 \pm 1.3$ & $-21.2 \pm 1.1$ & $10.9 \pm 0.5$ & $10.7 \pm 0.5$ & $3.8 \pm 0.0$ & $3.8 \pm 0.0$ \\
\hline & 2011 & PM & 42 & $-21.2 \pm 1.2$ & $-21.4 \pm 1.0$ & $10.9 \pm 0.5$ & $10.8 \pm 0.4$ & $3.8 \pm 0.0$ & $3.8 \pm 0.0$ \\
\hline & 2012 & PM & 41 & $-21.2 \pm 0.7$ & $-21.4 \pm 0.7$ & $10.6 \pm 0.4$ & $10.4 \pm 0.3$ & $3.8 \pm 0.0$ & $3.8 \pm 0.0$ \\
\hline \multirow[t]{5}{*}{ Blood plasma } & 2012 & $\mathrm{~PB}$ & 12 & $-24.5 \pm 0.3$ & $-26.1 \pm 1.3^{a}$ & $9.7 \pm 0.3$ & $9.1 \pm 0.5^{\mathrm{a}}$ & $5.4 \pm 0.4$ & $9.3 \pm 3.1^{\mathrm{a}}$ \\
\hline & & Inc & 22 & $-24.1 \pm 0.5$ & $-23.4 \pm 0.8$ & $9.7 \pm 0.3$ & $10.1 \pm 0.3$ & $5.2 \pm 0.2$ & $5.3 \pm 0.1$ \\
\hline & & BG & 9 & - & $-21.9 \pm 0.2$ & - & $10.3 \pm 0.6$ & - & $5.4 \pm 0.2$ \\
\hline & & $\mathrm{Cr}$ & 29 & $-21.9 \pm 0.4$ & $-21.7 \pm 0.3$ & $9.3 \pm 0.2$ & $9.4 \pm 0.4$ & $5.2 \pm 0.2$ & $5.3 \pm 0.2$ \\
\hline & & PM & 30 & $-23.0 \pm 1.1$ & $-22.9 \pm 1.0$ & $10.0 \pm 0.3$ & $10.2 \pm 0.2$ & $5.0 \pm 0.2$ & $5.1 \pm 0.3$ \\
\hline \multirow[t]{5}{*}{ Blood cells } & 2012 & $\mathrm{~PB}$ & 20 & $-22.4 \pm 0.3$ & $-22.4 \pm 0.5$ & $7.8 \pm 0.5$ & $7.7 \pm 0.4$ & $3.8 \pm 0.0$ & $3.4 \pm 0.0$ \\
\hline & & Inc & 22 & $-22.9 \pm 0.2$ & $-22.2 \pm 0.5$ & $9.4 \pm 0.2$ & $9.6 \pm 0.3$ & $3.8 \pm 0.0$ & $3.8 \pm 0.1$ \\
\hline & & BG & 9 & - & $-21.8 \pm 0.4$ & - & $9.9 \pm 0.3$ & - & $3.8 \pm 0.0$ \\
\hline & & $\mathrm{Cr}$ & 22 & $-21.6 \pm 0.3$ & $-20.9 \pm 0.5$ & $9.8 \pm 0.3$ & $9.5 \pm 0.3$ & $3.8 \pm 0.0$ & $3.8 \pm 0.0$ \\
\hline & & PM & 27 & $-21.0 \pm 0.6$ & $-20.9 \pm 0.5$ & $9.5 \pm 0.4$ & $9.4 \pm 0.3$ & $3.8 \pm 0.0$ & $3.8 \pm 0.0$ \\
\hline
\end{tabular}


centrifuged within 5 min of collection using a small bench-top centrifuge (MSE Micro Centaur, Sanyo; maximum $g=13400$ ) that was powered by a portable inverter generator (1000 W EU inverter 10i, Honda). The blood plasma was decanted immediately in order to avoid the use of anticoagulants (Lemons et al. 2012). All samples were frozen and stored at $-20^{\circ} \mathrm{C}$ until prepared for analysis. The estimated turnover rate of penguin blood cells was ca. 32 d (Cherel et al. 2007, Thiebot et al. 2014) and ca. $7 \mathrm{~d}$ for blood plasma (Barquete et al. 2013). The different turnover rates allowed diet information to be obtained at different temporal scales, whilst tissues with similar temporal resolution (blood plasma and feathers) permitted the presence of intrapopulation variation to be cross-validated. A tissue correction factor was not employed because direct comparisons between the different tissue types were not made (Dalerum \& Angerbjörn 2005).

Feather samples collected in different years

Macaroni penguins renew their entire plumage each year during a single moult period that occurs at the end of the breeding season (Brown 1986; Table 1). The tip of the feather is synthesised at sea during the pre-moult foraging trip (Cherel et al. 2005). Feathers collected before this trip therefore represented the pre-moult phase in the preceding year, whilst feathers collected after this trip represented the pre-moult phase of the sampling year. Black (dorsal) feathers were collected prior to the pre-moult foraging trip during 2002, 2003, 2004 and 2012. The birds sampled during 2012 were also sampled after moult, and these individual-level samples were used to assess specialisation between years. The top $5 \mathrm{~mm}$ of vane was retained for stable isotope analysis (Cherel et al. 2005), using 2 feather tips per individual. Only black feathers were included because preliminary analysis indicated that feather pigment had a significant influence on isotope ratios (methods and results are detailed in Supplement 2; www.int-res.com/articles/suppl/m548p233_supp.pdf).

\section{Breeding success and individual traits}

The 200 nests marked at the beginning of the 2012 breeding season were visited daily between egg laying and the onset of crèche. Chicks abandon individual nest sites during crèche, making individual fates difficult to monitor from this point onwards. Chick survival to the start of crèche was used as a proxy for individual breeding success. Breeding adults were identified by their passive integrated transponder (PIT) tags (Texas Instruments), which were scanned using a hand-held PIT reader (ISO RFID stick reader RS320-3-60, Allflex). Birds were also sexed using bill dimensions and by observing nest attendance patterns (Williams \& Croxall 1991). Body mass following the incubation trip was estimated to the nearest $0.05 \mathrm{~kg}$ by weighing birds with a Pesola spring balance within $1 \mathrm{~d}$ of return. Finally, the timing of breeding was measured using the laying date of the B-egg expressed as number of days since 1 November. Macaroni penguins lay 2 eggs, but near-complete failure of the first-laid A-egg means that they effectively produce a single-egg clutch (Williams 1995).

\section{Intrapopulation variation in habitat use}

A subset $(\mathrm{n}=38)$ of the individuals sampled for stable isotope analysis during the 2012 study period was also tracked using GPS devices (Sirtrack F2G $134 \mathrm{~A}$ [ $69 \times 28 \times 21 \mathrm{~mm}, 39 \mathrm{~g}$ ]; ca. $1.3 \%$ of mean adult body mass; see Table 3 for sample sizes). For the incubation and premoult trips, GPS devices were deployed before departure and retrieved when the birds returned after 12 to $16 \mathrm{~d}$ (mean $=13, \mathrm{SD}=1$, sampling frequency for GPS fixes = 15 min to maximise memory and battery capacity). For the brood-guard and crèche foraging trips, GPS deployments lasted for 2 to $11 \mathrm{~d}$ (mean $=4, \mathrm{SD}=2$; sampling frequency for GPS fixes $=5 \mathrm{~min}$ ).

Tracking data collected during the year and breeding phase that Bearhop et al. (2006) found evidence for iso-

\begin{tabular}{|lcccccr|}
\hline $\begin{array}{l}\text { Breeding } \\
\text { phase }\end{array}$ & \multicolumn{3}{c}{$\begin{array}{c}\text { No. of individuals } \\
\text { Male Female } \\
\text { Class 3 }\end{array}$} & $\begin{array}{c}\text { Male Female } \\
\text { Class 4 }\end{array}$ & \multicolumn{2}{c|}{$\begin{array}{c}\text { Maximum distance from } \\
\text { the colony }(\mathrm{km})\end{array}$} \\
& \multicolumn{2}{c}{ Class 3 } & Class 4 \\
\hline $\begin{array}{l}\text { Incubation } \\
\text { Brood }\end{array}$ & 3 & 1 & 0 & 5 & $476 \pm 82$ & $360 \pm 52$ \\
Crèche & - & 0 & - & 14 & - & $21 \pm 15$ \\
Pre-moult & 0 & 0 & 5 & 6 & - & $28 \pm 32$ \\
& 0 & 0 & 2 & 2 & - & $357 \pm 40$ \\
\hline
\end{tabular}


topic variation within the same population were also examined $(n=15)$. Birds were tracked during the crèche phase of the 2002 breeding season using ARGOS satellite transmitters (Telonics ST10 devices $[95 \times 42 \times 20 \mathrm{~mm}, 85 \mathrm{~g}]$, Sirtrack Kiwisat 10 [130 × 35 $\times 20 \mathrm{~mm}, 100 \mathrm{~g}$ ] and Wildlife Computers SPOT4 [90 $\times$ $20 \times 15 \mathrm{~mm}, 70 \mathrm{~g}]$; all devices $<2.3 \%$ of the adult mass). ARGOS deployments lasted for 1 to $13 \mathrm{~d}$ (mean $=6, \mathrm{SD}=3$; sampling frequency for ARGOS fixes $=10 \mathrm{~min}$ ). The 2002 tracking study was focused on examining spatial distribution and therefore did not involve concurrent blood sampling. All devices were attached dorsally using waterproof tape (Tesa AG), quick-setting 2-part epoxy glue (RS components) and cable ties.

\section{Sample preparation for stable isotope analysis}

Before stable analysis, blood cells and blood plasma were freeze-dried for 12 to $24 \mathrm{~h}$. Dried samples of blood cells were homogenised using a ball mill (TissueLyser II, Qiagen), and dried samples of blood plasma were homogenised manually to limit sample loss. Small sample volumes precluded lipid extraction to be undertaken on the blood plasma samples (Cherel et al. 2005); instead, variable lipid content between the different phases was assessed using the C:N ratios. Feathers were cleaned of surface contaminants using a 2:1 (v/v) chloroform:methanol rinse, repeated twice for $30 \mathrm{~min}$ in an ultra-sonic bath. This was followed by a 1:2 (v/v) chloroform:methanol rinse, repeated twice for $30 \mathrm{~min}$ in an ultra-sonic bath, and a final water rinse (Folch et al. 1957). Feathers were freeze-dried for 12 to $24 \mathrm{~h}$ after cleaning. Fractionation of ${ }^{15} \mathrm{~N}$ owing to the cleaning process was checked by comparing the $\delta^{15} \mathrm{~N}$ ratios of cleaned and uncleaned feathers for a subset of individuals $(\mathrm{n}=16)$; fractionation was not found (methods are detailed in Supplement 2).

Carbon and nitrogen isotopic measurements were determined by continuous-flow isotope ratio mass spectrometry, undertaken at the Scottish Universities Environmental Research Centre, East Kilbride. All analyses were performed using an automated elemental analyser (Costech ECS 4010) coupled in continuous-flow mode to an isotope-ratio-monitoring mass spectrometer (Thermo Fisher Scientific Delta V mass spectrometer). Single subsamples of $0.7 \mathrm{mg}$ aliquots were analysed in tin capsules. To correct for instrumental drift, each analytical sequence included 3 internal standards (gelatine [Fluka], glycine and alanine [Sigma-Aldrich]) for every 10 tissue samples.
Stable isotope concentrations are measured as the ratio of the heavier isotope to the lighter isotope relative to the international standards Vienna PeeDee Belemnite (carbon) and atmospheric $\mathrm{N}_{2}$ (AIR) (Hoefs 1997). Isotopic results are reported as $\delta$ values $\left(\delta^{13} \mathrm{C}\right.$ and $\delta^{15} \mathrm{~N}$ ) in parts per 1000 (per mille, \%o), using the following calculation:

$$
\delta X=\left[\left(R_{\text {sample }} / R_{\text {standard }}\right)-1\right] \times 1000
$$

where $X$ is ${ }^{15} \mathrm{~N}$ or ${ }^{13} \mathrm{C}$ and $R$ is the corresponding ratio ${ }^{15} \mathrm{~N} /{ }^{14} \mathrm{~N}$ or ${ }^{13} \mathrm{C} /{ }^{12} \mathrm{C}$. Based on replicate measurements of laboratory and international standards, measurement precision of both $\delta^{13} \mathrm{C}$ and $\delta^{15} \mathrm{~N}$ was estimated to be $\leq 0.2 \%$. All values presented are means $\pm 1 \mathrm{SD}$.

\section{Analysis}

Intrapopulation variation in isotope ratios and breeding constraints

In line with many previous isotopic studies of diet, initial data exploration was undertaken using linear models (Wilks MANOVA and ANOVA; Bearhop et al. 2006, Cherel \& Hobson 2007). These models included sex and time as fixed factors, but the residuals of the best candidate model indicated clustering that could not be attributed to the available covariate information (details in Supplement 3; www.int-res. com/articles/suppl/m548p233_supp.pdf). This violated the assumption that the spread of possible isotopic values was the same for each level of the measured covariates (the homogeneity assumption; Zuur et al. 2007). Therefore, linear modelling approaches were considered unsuitable for analysing this data set, and finite Gaussian (FG) mixture models were used to objectively group individual samples based on the combined $\delta^{13} \mathrm{C}$ and $\delta^{15} \mathrm{~N}$ data. These models were fitted in program $\mathrm{R}$ using the statistical package mclust (Fraley et al. 2014). The number of groups, hereon referred to as classes, within each tissue type was determined using the Bayesian information criterion (BIC) and were described as Gaussian kernels each with their own variance-covariance structure.

\section{Relationship between individual traits, breeding success and isotopic class}

The effect of sex on class membership of individuals was examined using blood plasma to represent the incubation foraging trip during 2012, and feather samples to represent the pre-moult foraging trips of 5 
separate years. The proportion of individuals within the incubation classes was also examined in relation to breeding success, body mass and timing of breeding. Body mass was standardised within each sex (by subtracting the group mean) to control for sexspecific changes during the incubation foraging trip (Table 1). Information on breeding success, body mass and timing of breeding was not available for the $5 \mathrm{yr}$ data set of feathers, and blood plasma samples representing the pre-moult foraging trip were not included because the available information on individual traits largely reflected the early breeding season (body mass after the incubation foraging trip, timing of laying and breeding success to crèche).

The influence of covariates was examined using binomial generalised linear models (GLMs) with logit link functions. The response variable was a binary factor where each level represented an isotopic class. Multi-collinearity between the covariates was checked using variance inflation factors (VIFs, calculated using the R statistical package car; Fox et al. 2015); a VIF score of greater than 5 was taken to represent collinearity (Rogerson 2001). The goodness-of-fit of the starting models was evaluated by calculating the pseudo-coefficient of determination (pseudo- $\mathrm{R}^{2}$ ) as [1 - (residual deviance/null deviance)] (Swartzman et al. 1992). Here, the null deviance is the total deviance in the model, and the residual deviance is the difference between the data and the model. The starting models included all of the main effects, and the best candidate model (i.e. the model containing the most informative set of covariates) was selected based on the second-order corrected Akaike's information criterion $\left(\mathrm{AIC}_{\mathrm{c}}\right)$. A difference of more than $2 \mathrm{AIC}_{\mathrm{c}}$ units was taken to indicate strong support for the model with the lower $\mathrm{AIC}_{\mathrm{C}}$ and a difference of less than 2 was taken to suggest that competing models received a similar amount of support from the data (Burnham \& Anderson 2002). In this case, all of the best candidate models were presented.

Intrapopulation variation in isotope ratios and extrinsic conditions

Acoustic surveys carried out in a standard area to the northwest of South Georgia documented a 3-fold change in local krill density during the 5 years with available feather data (Fielding et al. 2014). The density of krill was very low in $2001\left(<30 \mathrm{~g} \mathrm{~m}^{-2}\right)$, highly abundant in $2002\left(137 \mathrm{~g} \mathrm{~m}^{-2}\right)$ and intermediate in the other 3 years ( 60 to $90 \mathrm{~g} \mathrm{~m}^{-2}$; Fielding et al. 2014). The recruitment of krill at South Georgia is thought to reflect seasonal advection from spawning grounds farther south (Atkinson et al. 2004), and therefore the life stage and oceanic origin of these krill may vary annually (Frazer et al. 1997, Trull \& Armand 2001, Schmidt et al. 2003, Stowasser et al. 2012). To control for any yearly fluctuations in basal isotopic signature the stable isotope ratios of feathers were standardised within each year by subtracting the annual mean.

An FG mixture model was used to test for discrete isotopic classes in the feather data using the combined $\delta^{13} \mathrm{C}$ and $\delta^{15} \mathrm{~N}$ data. Annual variation in the distribution of individuals between the resulting isotopic classes was examined using the same model that tested for the effect of sex (see 'Relationship between individual traits, breeding success and isotopic class'). Year was included in the starting model as a fixed factor to account for annual variation in extrinsic conditions. Finally, annual variation in the isotope ratios of each class was quantified using Euclidean distances and the position of individuals in the $\delta^{13} \mathrm{C}$ and $\delta^{15} \mathrm{~N}$ bi-plot space (Layman et al. 2007). Layman et al. (2007) used this approach to assess diversity at the community level by comparing distances between different species. We applied this method at the population level, comparing the mean distance of individuals to the centroid (CD) of their isotopic class in different years. The $\mathrm{CD}$ was the mean $\delta^{13} \mathrm{C}$ and $\delta^{15} \mathrm{~N}$ of each class.

Relationship between habitat use and isotopic class

The maximum distance travelled from the colony $(\mathrm{km})$ and the most likely path that a penguin followed were derived in program $\mathrm{R}$ using the statistical packages trip and tripEstimation, respectively (Sumner \& Luque 2013, Sumner \& Wotherspoon 2013, R Development Core Team 2014). Intermediate points were modelled using a log-normal distribution to stochastically assign initial swim speeds (mean $=2 \mathrm{~km} \mathrm{~h}^{-1}$, $\mathrm{SD}=1$; derived from satellite tracking of rockhopper penguins Eudyptes chrysocome; Raya Rey et al. 2007). Observation error was based on the respective error of the GPS device or ARGOS location class. In total 5 chains of 2000 iterations were simulated, discarding the initial 500 iterations as burn-in. The comparison between tracking data and stable isotope ratios was made using blood plasma. Blood cells were not included because the turnover rate was longer than the individual breeding phases. The blood plasma data provided an integrated signal of several short trips during brood-guard and crèche, and a signal from around the middle of the trip, to the 

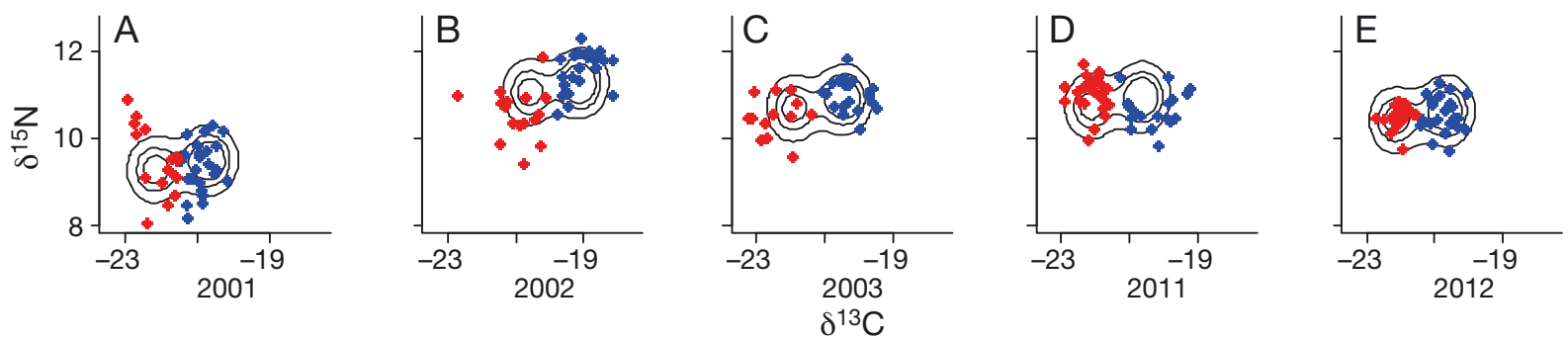

Fig. 1. Annual variation in the stable isotope ratios of macaroni penguins during the pre-moult foraging trip. Black feather samples were collected from macaroni penguins to represent 5 years that spanned a 3-fold difference in local krill density. Two distinct isotopic classes are shown: Class 1 (red) and Class 2 (blue). Data points shown as de-standardised. Density contours (black lines) shown for total data set at $0.25,0.50$ and 0.75

time of return, during incubation and pre-moult. For the longer trips, this included the period when birds were furthest from the colony and residency times typically increase, which is indicative of foraging (Lowther et al. 2014).

\section{Individual specialisation in isotopic class across 2 years}

A randomisation test was used to statistically compare the observed probability that individuals remained within the same pre-moult isotopic class across 2 consecutive years with the expected probability of specialisation if assignment occurred by chance. The observed probability was estimated using feathers collected from the same individual before and after moult during the 2012 breeding season $(n=20)$. The expected probability was estimated by pooling all of the feather data $(\mathrm{n}=196 ; 5$ years $)$ and calculating the conditional probability of an individual remaining in the same isotopic class across years. For example, if 2 classes (say, $A$ and $B$ ) are present in each year, the probability $(P)$ of consistent membership $(M)$ between Year $1\left(T_{1}\right)$ and Year $2\left(T_{2}\right)$ would be calculated as follows:

$$
P(M)=P\left(T_{1}=A \cap T_{2}=A\right)+P\left(T_{1}=B \cap T_{2}=B\right)
$$

To compare the observed and expected probability we simulated the number of individuals expected to stay within the same isotopic class between years using a binomial distribution with probability equal to the pooled feather data and sample size equal to the observed data $(n=20)$. Sampling was repeated for 10000 iterations, and the proportion of samples that estimated the expected number of specialised individuals to be equal to the observed number was used as a significance test. Here, a small proportion of samples indicated that consistent isotopic classification did not occur by chance.

\section{RESULTS}

Blood plasma samples collected from female macaroni penguins at the start of the breeding season showed signs of excess lipid (increased C:N ratio; Table 2). This was possibly associated with the yolk precursor vitellogenin (Crossin et al. 2010), and therefore these samples were removed from further analysis. Consistent variation in the $\mathrm{C}: \mathrm{N}$ ratios of the remaining blood plasma samples, and the lack of a clear relationship between $\mathrm{C}: \mathrm{N}$ ratio and $\delta^{13} \mathrm{C}$, was taken to indicate relatively constant levels of lipid across the other phases of the annual cycle for both sexes (Table 2). The final data set comprised 196 cleaned black feather samples, 102 blood plasma samples and 105 blood cell samples (Table 2; see Supplement 3). A total of 2 isotopic classes were identified in feathers (Fig. 1; Classes 1 and 2) and blood plasma (Fig. 2A-E; Classes 3 and 4), and 4 were identified in blood cells (Fig. 2F-J; Classes 5 to 8). The mean values and SDs for these classes are detailed in Table 4.

\section{Intrapopulation variation in isotopic ratios and breeding constraints}

A single class was identified in the samples of blood cells (turnover rate ca. $32 \mathrm{~d}$ ) that represented the pre-breeding season (Fig. 2A,F). This class had lower $\delta^{15} \mathrm{~N}$ values and a larger range of $\delta^{13} \mathrm{C}$ values than the other classes observed in this tissue later in the breeding season (Fig. 2F-J). A single isotopic class was also identified in the blood plasma (turnover rate ca. 7 d) samples for males that represented the pre-breeding season. This class was within the $\delta^{13} \mathrm{C}$ and $\delta^{15} \mathrm{~N}$ range observed for this tissue during the incubation and pre-moult phases of the subsequent breeding season (Fig. 2A,B,E). 

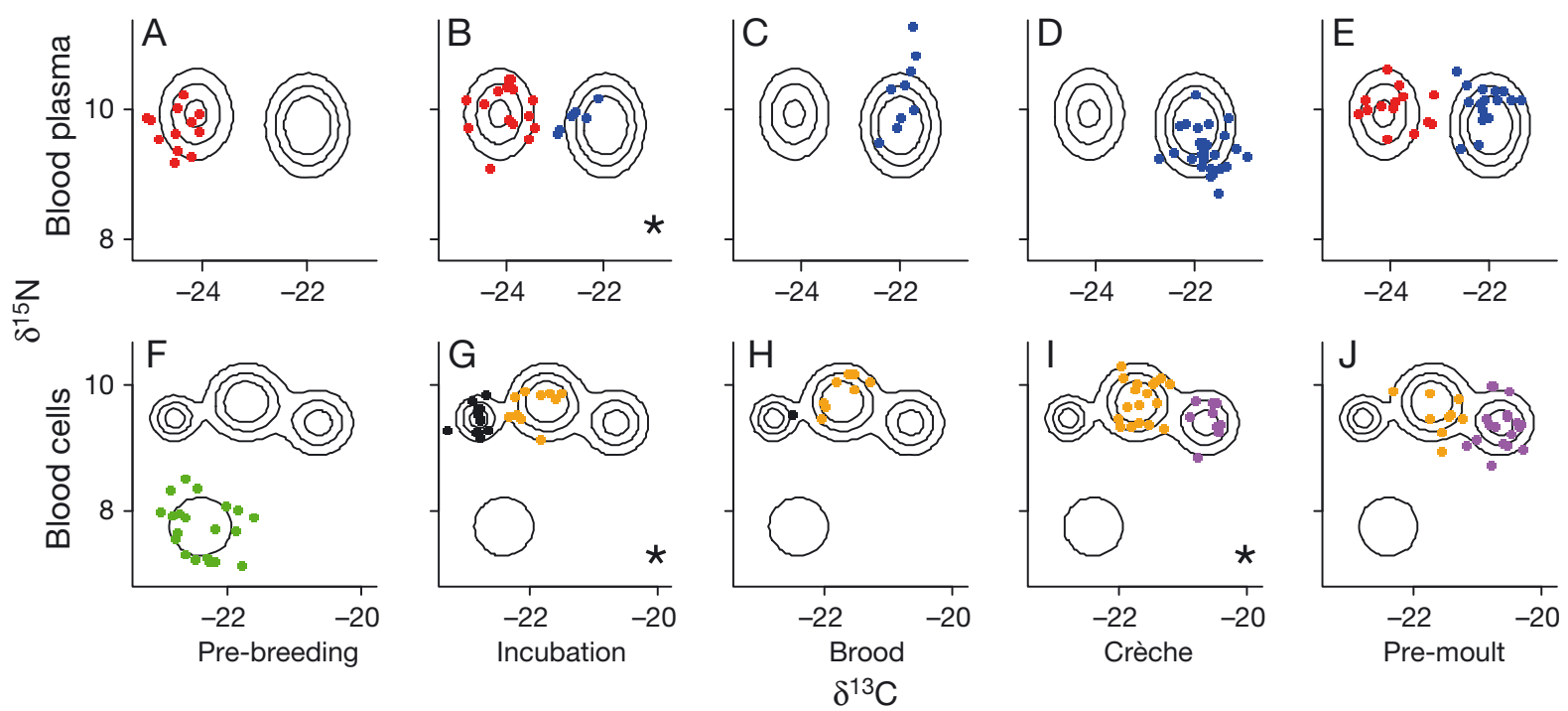

Fig. 2. Intrapopulation variation in the stable isotope ratios of macaroni penguins within the annual cycle: (A-E) Blood plasma displays 2 distinct classes: Class 3 (red) and Class 4 (blue); and (F-J) blood cells display 4 distinct classes: Class 5 (green), Class 6 (black), Class 7 (orange) and Class 8 (purple). Differences in the $x$-axis between the 2 tissue types reflect tissue-specific isotopic fractionation. Breeding phases that resulted in at least 1 sex-specific class are indicated with an asterisk: (B) Class 4 (blue) contains only females; (G) Class 7 (orange) contains only females; and (I) Class 8 (purple) contains only females. Only females were sampled during brood-guard $(C, H)$. All other plots $(A, D, E, F, J)$ included both sexes in all classes. Density contours (black lines) shown for total data set at $0.25,0.50$ and 0.75 ; empty contours indicate that the isotopic class was not identified in the specific phase

Two $\delta^{13} \mathrm{C}$ classes were identified during the premoult foraging trip in all 3 tissues. These classes were not identical in isotope values; however, the isotopic difference between the mean values was similar $(\sim 2.0 \%$; Figs. 1E \& 2E,J, Table 4). In the blood plasma samples, these 2 isotopic classes were also present during the incubation foraging trip. Class 3 was char-

Table 4. Mean and SD of the isotopic classes that were identified within each tissue

\begin{tabular}{|lccccc|}
\hline Sample & Year & Class & $\delta^{13} \mathrm{C}$ & $\delta^{15} \mathrm{~N}$ & $\mathrm{SD}$ \\
\hline Feather & 2001 & 1 & -22.2 & 9.3 & 0.3 \\
& & 2 & -20.7 & 9.5 & 0.3 \\
& 2002 & 1 & -20.6 & 11.1 & 0.3 \\
& & 2 & -19.1 & 11.3 & 0.3 \\
& 2003 & 1 & -22.0 & 10.7 & 0.3 \\
& & 2 & -20.4 & 10.90 & 0.3 \\
& 2011 & 1 & -22.2 & 10.7 & 0.3 \\
& & 2 & -20.6 & 10.9 & 0.3 \\
Blood plasma & 2012 & 1 & -22.2 & 10.4 & 0.3 \\
& & 2 & -20.6 & 10.6 & 0.3 \\
Blood cells & 2012 & 3 & -24.1 & 9.9 & 0.2 \\
& & 4 & -22.0 & 9.8 & 0.2 \\
& 2012 & 5 & -22.4 & 7.8 & 0.2 \\
& & 6 & -22.8 & 9.5 & 0.1 \\
& & 7 & -21.7 & 9.7 & 0.1 \\
& & 8 & -20.6 & 9.4 & 0.1 \\
\hline
\end{tabular}

acterised by consistently lower $\delta^{13} \mathrm{C}$ values (ca. -25.0 to $-23.0 \%$ ) than Class 4 (ca. -23.0 to $-21.0 \%$ ), and all individuals appeared within Class 4 during broodguard and crèche (Table 4). Classes 3 and 4 had similar $\delta^{15} \mathrm{~N}$ ratios that remained relatively constant through time (ca. 9.0 to $11.0 \%$; Fig. 2A-E). The 3 classes that were present in blood cells during the breeding and pre-moult phases increased in $\delta^{13} \mathrm{C}$ over time, i.e. individuals were in Classes 6 and 7 during incubation (ca. -23.0 to $-21.0 \%$ ), were almost exclusively in Class 7 during brood-guard (ca. -22.0 to $-21.0 \%$ ) and were in Classes 7 and 8 during crèche and pre-moult (ca. -22.0 to $-20.0 \%$ ) (Fig. 2F-J). In contrast, the $\delta^{15} \mathrm{~N}$ ratios of these classes remained relatively constant over the same time period (ca. 9 to $10.5 \%$ ).

\section{Relationship between individual traits, breeding success and isotopic class}

The distribution of individuals between the 2 isotopic classes that were present in blood plasma during the incubation foraging trip did not significantly relate to sex (GLM: $z=-0.01, p=0.99$ ), body mass (GLM: $z=-1.73, p=0.08$ ), breeding success (to the start of crèche) (GLM: $z=0.01, p=0.99$ ) or timing of breeding (GLM: $z=1.16, p=0.25$ ) (GLM: pseudo- 
Table 5. Candidate models for examining the relationship between individual traits, breeding success, year and isotopic class. Blood plasma samples collected following the incubation foraging trip were used to examine the relationship between isotopic class, breeding success and individual traits (sex, body mass and timing of breeding [Time_b]). The null model and models within 2 corrected Akaike's information criterion $\left(\mathrm{AIC}_{\mathrm{c}}\right.$ ) units of the best candidate model are shown. Feather samples reflecting the pre-moult foraging trip were used to examine the relationship between isotopic class and annual changes in extrinsic conditions; all candidate models are shown. All effect sizes reflect the predicted difference between the 2 isotopic classes and sex (M) shows the effect size of males relative to females. "Year was included as a factor and the effect size shown is the mean value. Dashes show variables not included in the respective starting model

\begin{tabular}{|c|c|c|c|c|c|c|c|c|c|}
\hline \multirow[t]{2}{*}{ Tissue type } & \multicolumn{5}{|c|}{ Model structure and effect size of variable $( \pm \mathrm{SE})-$} & \multirow[t]{2}{*}{ df } & \multirow{2}{*}{$\mathrm{AIC}_{\mathrm{c}}$} & \multirow[t]{2}{*}{$\Delta \mathrm{AIC}_{\mathrm{c}}$} & \multirow[t]{2}{*}{ Weight } \\
\hline & $\operatorname{Sex}(\mathrm{M})$ & Body mass & Breeding success & Time_b & ${ }^{*}$ Year & & & & \\
\hline \multirow[t]{6}{*}{ Blood plasma } & $-40.4\left( \pm 7.5 \times 10^{4}\right)$ & $-10.5( \pm 6.7)$ & $20.2\left( \pm 5.6 \times 10^{4}\right)$ & & - & 4 & 23.8 & 0.0 & 0.2 \\
\hline & $-20.6\left( \pm 3.4 \times 10^{4}\right)$ & $-7.0( \pm 4.9)$ & & & - & 3 & 24.2 & 0.4 & 0.2 \\
\hline & $-19.2\left( \pm 4.1 \times 10^{4}\right)$ & & & & - & 2 & 24.8 & 1.0 & 0.1 \\
\hline & $-38.0\left( \pm 8.6 \times 10^{4}\right)$ & & $19.1\left( \pm 6.4 \times 10^{4}\right)$ & & - & 3 & 25.6 & 1.8 & 0.1 \\
\hline & $-43.4\left( \pm 7.0 \times 10^{4}\right)$ & $-18.8( \pm 10.9)$ & $22.8\left( \pm 5.3 \times 10^{4}\right)$ & $0.6( \pm 0.6)$ & - & 5 & 25.6 & 1.8 & 0.1 \\
\hline & & & & & - & 1 & 28.0 & 4.2 & 0.0 \\
\hline \multirow[t]{4}{*}{ Feather } & & - & - & - & & 1 & 271.7 & 0.0 & 0.5 \\
\hline & $-0.4( \pm 0.3)$ & - & - & - & & 2 & 271.9 & 0.2 & 0.4 \\
\hline & & - & - & - & $0.2( \pm 0.5)$ & 5 & 276.2 & 4.5 & 0.1 \\
\hline & $-0.4( \pm 0.3)$ & - & - & - & $0.2( \pm 0.5)$ & 6 & 276.5 & 4.8 & 0.0 \\
\hline
\end{tabular}

$\left.\mathrm{R}^{2}=0.59, \mathrm{df}=17\right)$. However, model selection identified 5 comparable candidate models that all included sex; 3 of these also included body mass, 3 included breeding success and 1 included timing of breeding (Table 5). The influence of sex and breeding success were not resolvable based on effect size and standard errors (Table 5). The lack of information on breeding success is likely to reflect the available sample size; only 4 of the 22 breeding pairs failed their breeding attempt before the onset of crèche (3 males in Class 3, 1 female in Class 4). For sex, this is likely to reflect the skewed distribution of males, but not females, towards the lower $\delta^{13} \mathrm{C}$ class (Fig. 3). The higher $\delta^{13} \mathrm{C}$ class from the incubation trip (Class 4 )

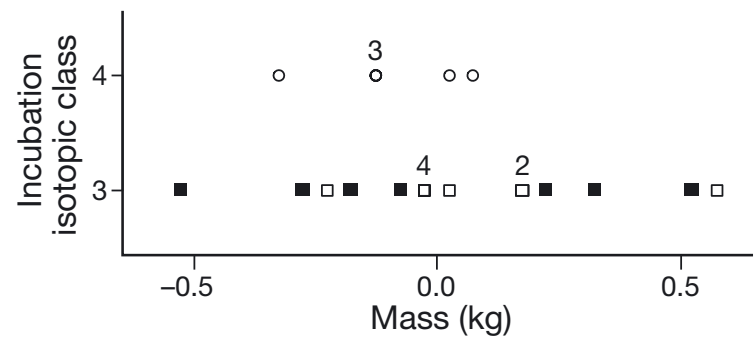

Fig. 3. Influence of sex and mass on the distribution of individuals between the 2 isotopic classes that were present during the incubation foraging trip. Males gain more mass during this phase (Table 1), and therefore body mass was standardised within each sex by subtracting the group mean. Isotopic Class 3 (squares) and Class 4 (circles) shown as females (open symbols) and males (closed symbols; males were not identified in Class 4 during incubation). Numbers above points indicate duplicates: Class 4 includes 6 females; Class 3 includes 9 females and 7 males included only females, whereas the lower $\delta^{13} \mathrm{C}$ class included both sexes (Class 3; 7 males and 9 females; Supplement 3, Table S3.1). Therefore, females had slightly higher $\delta^{13} \mathrm{C}$ values than males following the incubation foraging trip (Fig. 2B, Table 2). Possible relationships with body mass and timing of breeding were suggested, whereby female macaroni penguins in the lower $\delta^{13} \mathrm{C}$ class may be slightly more likely to have a larger body mass than females in the higher $\delta^{13} \mathrm{C}$ class (Fig. 3). Furthermore, birds in the lower $\delta^{13} \mathrm{C}$ class may be more likely to initiate breeding slightly earlier (Table 5).

The distribution of individuals between the 2 feather classes also did not significantly relate to sex (GLM: pseudo- $\mathrm{R}^{2}=0.02, \mathrm{df}=190, z=-1.36, \mathrm{p}=0.18$ ). However, model selection identified that a model including sex was equally well supported by the data as a model that did not include any covariates. The effect size of sex on isotopic class indicated that males were slightly more likely to be in the lower $\delta^{13} \mathrm{C}$ class (Table 5). In agreement with the results from the incubation foraging trip, males were slightly more prevalent in the lower $\delta^{13} \mathrm{C}$ class during premoult (Class $1=57$ males, Class $2=38$ males; Supplement 3, Table S3.1), with females equally distributed between both classes (Class $1=50$ females, Class $2=51$ females; Supplement 3, Table S3.1) (Table 5). Finally, sex-specific classes were also present in blood cells during multiple phases. During incubation and crèche the lower $\delta^{13} \mathrm{C}$ class contained both sexes, whereas the higher $\delta^{13} \mathrm{C}$ class contained only females (Class 7; Fig. 2G,I). 

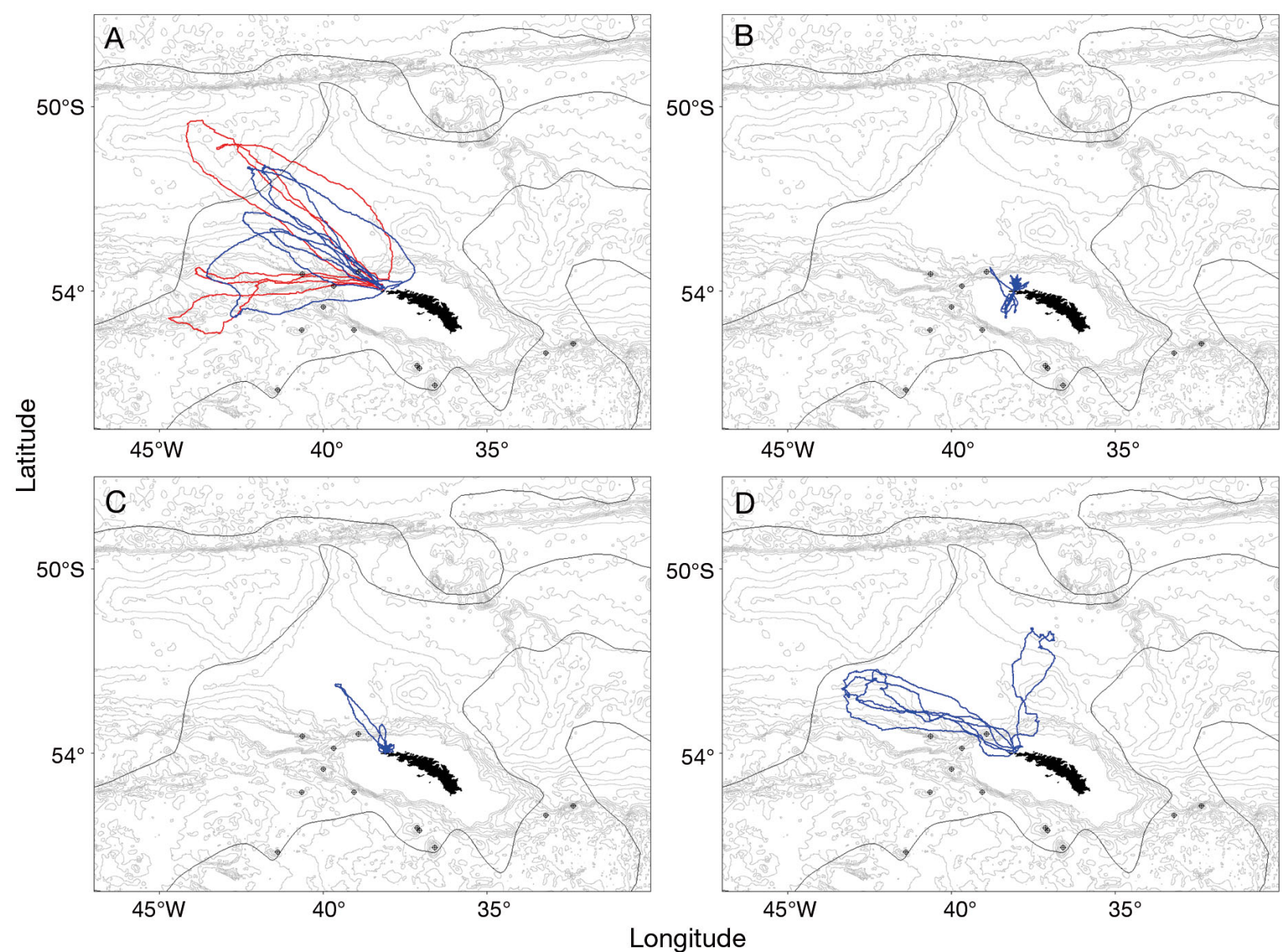

Fig. 4. Intrapopulation variation in the foraging range of macaroni penguins breeding on Bird Island, South Georgia during (A) incubation, (B) brood-guard, (C) crèche and (D) pre-moult. Isotope classes assigned using concurrently collected blood plasma: Class 3 (red) and Class 4 (blue). Average position of ocean fronts are shown as black lines; from the top down: SubAntarctic Front; Antarctic Polar Front; Southern Antarctic Circumpolar Current Front; and Southern Antarctic Circumpolar Current Boundary. The general pattern of the surface current flow in the Scotia Sea is from west to east in line with the major ocean fronts. The study area, Bird Island, is at the western end of South Georgia (black area). Bathymetry contours (grey lines) every $500 \mathrm{~m}$; seamounts shown with black circles

\section{Intrapopulation variation in isotope ratios and extrinsic conditions}

The distribution of individuals between the 2 feather classes did not change between the 5 study years (GLM: pseudo- $\mathrm{R}^{2}=0.02$, all years $\mathrm{p}>0.05$ ). The pooled data set indicated that $55 \%$ of the population were consistently within the lower $\delta^{13} \mathrm{C}$ class (Class 1) and $45 \%$ were consistently within the higher $\delta^{13} \mathrm{C}$ class (Class 2; Fig. 1). The isotopic difference between the mean values of these classes also remained similar over time ( 2\%; Fig. 1), and Euclidean distances to the class CD did not significantly differ between isotopic class or year, with the exception of 2012 when CDs were shorter (Fig. $1 ; \mathrm{lm}: \mathrm{R}^{2}=0.12$, $F_{5,190}=5.27 ; 2012: t=-3.96, \mathrm{p}<0.001$, all other covariates $\mathrm{p}>0.05$ ).

\section{Relationship between habitat use and isotopic class}

GPS tracking carried out within the 2012 annual cycle demonstrated that maximum foraging distances from the colony decreased significantly when central-place constraints were greater, i.e. during the chick-rearing phases (Table 3, Fig. 4). The individuals tracked during the incubation foraging trip were from both $\delta^{13} \mathrm{C}$ classes that were identified for this phase. These individuals overlapped spatially, but those in the lower $\delta^{13} \mathrm{C}$ class (Class 3) travelled approximately $25 \%(116 \mathrm{~km})$ farther along the same orientation compared to those in the higher $\delta^{13} \mathrm{C}$ class (Class 4; Fig. 4A). The individuals tracked during the chick-rearing and pre-moult phases were all assigned to the higher $\delta^{13} \mathrm{C}$ blood plasma class (Class 4; Fig. 4B-D). During pre-moult, these individuals 
achieved similar maximum foraging distances to individuals with Class 4 ratios tracked during incubation (Fig. 4A,D, Table 3).

Foraging range was also examined for the year and breeding phase in which Bearhop et al. (2006) found evidence for isotopic variation in this population (crèche, 2002). The maximum foraging distance from the colony was greater and more variable during $2002($ mean $=65 \mathrm{~km}, \mathrm{SD}=65)$, compared to 2012 (mean $=28$ km, SD = 32; Supplement 3, Fig. S3.2) .

\section{Individual specialisation in isotopic class across 2 years}

Individual consistency in pre-moult isotopic class between years was examined using feather samples that represented 2 sequential years (2011 and 2012). The observed probability that an individual remained within the same isotopic class was $0.85 ; 8$ individuals stayed within the lower $\delta^{13} \mathrm{C}$ class (Class 1), 9 individuals stayed within the higher $\delta^{13} \mathrm{C}$ class (Class 2) and the remaining 3 individuals moved from Class 2 to Class 1. Based on the pooled data set, the expected probability of remaining within the same isotopic class if assignment occurred by chance was estimated to be mean $=0.51(\mathrm{SD}=0.01)$. The proportion of simulated samples that could estimate the observed proportion of specialised individuals based on the expected probability was $<0.001$, i.e. it was highly unlikely that individual consistency occurred by chance.

\section{DISCUSSION}

\section{Intrapopulation variation in resource use and intrinsic constraints}

\section{Breeding constraints}

Macaroni penguins are fully pelagic during the winter months, and the breeding population from Bird Island, South Georgia, disperses across multiple oceanic fronts during this period (Ratcliffe et al. 2014). The isotope samples that represented the prebreeding season (blood cell and blood plasma) did not demonstrate the discrete $\delta^{13} \mathrm{C}$ classes that are indicative of these fronts (Trull \& Armand 2001, Cherel \& Hobson 2007). However, the range of $\delta^{13} \mathrm{C}$ ratios in the blood cell data was comparable to the isotopic difference between the 2 classes reported by Cherel et al. (2007) for this phase (whole blood preserved in ethanol; $\sim 2.0 \%$ o). The lack of discrete classes identified in our study may therefore reflect mixed diets when birds are migrating through different water masses during the pre-breeding season.

The $\delta^{15} \mathrm{~N}$ values of blood cells representing the prebreeding season in 2012 indicated that macaroni penguins may have consumed lower trophic level prey during the month prior to breeding, compared to the subsequent breeding season. During the winter, myctophid fish at the Antarctic Polar Front (APF) are typically distributed lower in the water column (Koslov et al. 1991), inaccessible even for deeperdiving king penguins Aptenodytes patagonicus that migrate farther south to areas where myctophid fish occur at shallower depths (Charrassin \& Bost 2001, Bost et al. 2004). In contrast, macaroni penguins remain in more northerly waters (Ratcliffe et al. 2014), and may compensate for the lower availability of fish by switching to a diet that is almost entirely composed of crustaceans. The diets of macaroni penguins are then potentially enriched in ${ }^{15} \mathrm{~N}$ during the breeding season by the inclusion of myctophid and demersal fish species (Waluda et al. 2012). The blood plasma samples that represented the pre-breeding season for males were similar to those observed for males during incubation and spanned part of the range observed for males during pre-moult. Consequently, we infer that in the final ca. $7 \mathrm{~d}$ of the prebreeding season, male macaroni penguins foraged at least partially in the same water masses that are exploited during the incubation and pre-moult foraging trips. The lack of tracking information for the pre-breeding season precluded a direct comparison of habitat use during these phases.

Variable levels of central-place constraint associated with the demands of reproduction and moult coincided with differing levels of intrapopulation variation in $\delta^{13} \mathrm{C}$. When birds were able to conduct mid-range foraging trips (i.e. during incubation and pre-moult), individuals were distributed between 2 discrete isotopic classes, but when foraging ranges were highly restricted (i.e. during brood-guard and crèche), all individuals were grouped within one of these classes. Thus, it appears that an increase in central-place constraint during the chick-rearing phases prevented individuals from accessing the resources, or exploiting the ecological opportunities, that generated the lower $\delta^{13} \mathrm{C}$ class during the incubation and pre-moult foraging trips.

During incubation, individuals from the lower $\delta^{13} \mathrm{C}$ class travelled approximately $25 \%$ farther from the colony than birds in the higher $\delta^{13} \mathrm{C}$ class. This additional travel distance took some individuals into waters beyond the APF. Baseline $\delta^{13} \mathrm{C}$ is thought to in- 
crease north of the APF (Trull \& Armand 2001, Cherel \& Hobson 2007); however, the individuals that appeared to also exploit these waters had lower $\delta^{13} \mathrm{C}$ values than those foraging south of this feature. This variation may reflect greater ${ }^{13} \mathrm{C}$ enrichment of inshore food-webs compared with those offshore, a characteristic of marine food-webs in general (Hobson et al. 1994, France 1995). Here, the ${ }^{13} \mathrm{C}$ gradient could have migrated past the edge of the continental shelf, due to the advection of shelf water masses into oceanic waters by currents (Blain et al. 2001, Dunton et al. 2006) influenced by the retroflecting oceanographic features that wrap around South Georgia (Thorpe et al. 2002, Meredith et al. 2003). Individual preferences for resources that are indistinguishable based on stable isotope ratios may also occur during the chick-rearing phases, and fine-scale analysis of foraging behaviour (diving and tracking) with concurrent sampling of stomach contents may elucidate this.

\section{Individual traits}

The distribution of individuals between the 2 isotopic classes that were present during the incubation and pre-moult foraging trips was not significantly related to sex. However, for both trips males were slightly more prevalent in the lower $\delta^{13} \mathrm{C}$ class, whereas females appeared to be equally present in both classes. Model selection also indicated a marginal relationship between body mass and isotopic class during the incubation foraging trip. Here, females in the lower $\delta^{13} \mathrm{C}$ class may have slightly larger body masses compared to females in the higher $\delta^{13} \mathrm{C}$ class. Assuming that birds in the lower $\delta^{13} \mathrm{C}$ class are travelling farther offshore during the mid-range foraging trips, having a slightly larger body mass may permit individuals to exploit such resources more efficiently than smaller birds. Likewise, the skewed distribution of males towards lower $\delta^{13} \mathrm{C}$ class may reflect the slight sexual dimorphism that is present in macaroni penguins. This mechanism has been found in a variety of sexually dimorphic seabirds (Phillips et al. 2011).

Sex-specific isotopic classes were also identified in blood cells during incubation and crèche. In agreement with the trend observed for the mid-range foraging trips, the blood cell isotope ratios of females during crèche were enriched in ${ }^{13} \mathrm{C}$ compared to males. This difference is likely to reflect the inshore vs. offshore $\delta^{13} \mathrm{C}$ gradient, in addition to sex-specific specialisation in reproductive roles during broodguard. Female macaroni penguins switch from pelagic foraging during incubation to neritic foraging during brood-guard; however, the stable isotope ratios of males will not reflect this change because they were fasting onshore. This finding highlights the importance of considering tissue type and the temporal scales of interest when analysing the diet of species in which males and females differ in one or more aspects of their breeding behaviour. In contrast to Cherel et al.'s (2005) study on king penguins, tissues collected from male macaroni penguins following the brood-guard fast were not enriched in ${ }^{15} \mathrm{~N}$. The study by Cherel et al. (2005) examined stable isotope ratios during moult. Although macaroni penguins fast for a similar duration during brood-guard and moult, their daily energy expenditure is lower (Green et al. 2009) and the overall mass loss is less (Williams 1995; Table 1), indicating lower usage of endogenous reserves during brood-guard.

\section{Individual consistency and intrapopulation variation in resource use and extrinsic conditions}

The acquisition of resources during the pre-moult foraging trip will determine an individual's ability to complete the subsequent moulting period (GauthierClerc et al. 2001). Individuals appeared to be highly consistent in their pre-moult isotopic class between the 2 study years. Of the 3 individuals that changed class $(15 \%)$, all switched from the higher $\delta^{13} \mathrm{C}$ class (the inshore group) to the lower $\delta^{13} \mathrm{C}$ class (offshore group). A greater sampling effort is needed to clarify whether this switch may reflect factors such as increasing age and experience, and to examine plasticity in this trait over time. Intrapopulation variation in the isotopic classes present during the pre-moult foraging trip appeared to be highly consistent across years with large differences in krill density. Specialisation in habitat use may enable macaroni penguins to minimise intraspecific competition (Thiebot et al. 2011); however, individuals with highly specialised diets or foraging strategies may also be more vulnerable to fluctuations in prey availability (Bolnick et al. 2011). Therefore, an alternative explanation for the highly consistent level of isotopic variation between the 5 study years may be a mismatch between krill density in the waters surveyed near South Georgia and the offshore foraging grounds utilised by macaroni penguins during the pre-moult foraging trip. This would imply that offshore resources during the study period were consistently above a threshold that would otherwise change intrapopulation variation in resource use. 
A previous isotope study on this population of macaroni penguins identified intrapopulation variation in the ratios of blood cells collected from females in 2002 during crèche (Bearhop et al. 2006; 2\% difference between the mean values of 2 classes). The isotope ratios of blood cells collected from female macaroni penguins during 2012 did not show the same level of variability ( $<1.0 \%$ range). Given that our sample size was greater than that considered by Bearhop et al. (2006), it seems unlikely that this difference relates to lower statistical power during 2012. A comparison of maximum foraging distances achieved during the crèche period of 2002 and 2012 indicated that birds were traveling further and with greater intrapopulation variation during 2002. Altered activity budgets and diet switching in this population typically results from a reduction in local krill availability (Croxall et al. 1999, Waluda et al. 2010). The percentage of individuals with a diet dominated by krill ( $>90 \%$ of a diet sample) was lower in 2002 compared to 2012 (42\% in 2002; Waluda et al. 2012; $60 \%$ in 2012; British Antarctic Survey unpubl. data). Consequently, we infer that although krill occurred in greater density during 2002 (Fielding et al. 2014), they were distributed lower in the water column such that accessibility to foraging macaroni penguins was reduced.

\section{CONCLUSIONS}

Isotopic variation in macaroni penguins decreased during periods of the annual cycle with highly restricted foraging ranges (i.e. during chick-rearing) and increased when birds were able to make midrange foraging trips (i.e. during incubation and premoult). The discrete $\delta^{13} \mathrm{C}$ classes that were present during the incubation and pre-moult foraging trips were possibly associated with body mass, such that larger birds were able to exploit offshore resources more efficiently than smaller birds. This level of variation appeared to be highly consistent across years with a 3 -fold difference in local krill density, and was also highly consistent at the individual level between 2 years with similar krill densities. However, by comparing our results with Bearhop et al. (2006), it also appeared that a decrease in prey availability can generate greater isotopic variation and wider foraging distributions during phases of the annual cycle with highly restricted central-place constraints. We conclude that intrapopulation variation in resource use can change on multiple spatio-temporal scales in relation to intrinsic and extrinsic drivers of ecological opportunity.
Acknowledgements. Many thanks to Catherine Kneale (McDonald Institute for Archaeological Research, University of Cambridge), James Rolfe (Godwin Laboratory, Department of Earth Sciences, University of Cambridge) and those at Scottish Universities Environmental Research Centre for help with isotopic analyses. Thanks also to Dr. Ruth Brown, Jon Ashburner, Mick Mackey and Jennifer James for their assistance with fieldwork during 2012. We are also grateful to the Bird Island field assistants that supported collection of feather samples in previous years. Thanks are also extended to Dr. Tracey Rogers and Dr. Gabi Stowasser for early discussions on sample collection and preparation, to Dr. Ruedi Nager for comments on an earlier version of this manuscript, to Dr. Hannah Froy for discussions on the use of the trip package in R and to Dr. Sophie Fielding for valuable discussions regarding krill densities around South Georgia. Recognition is also extended to 4 anonymous reviewers for helpful comments on an earlier version of this manuscript. This study is part of the ecosystems component of the British Antarctic Survey Polar Science for Planet Earth Programme, funded by the Natural Environment Research Council (NERC). The analysis was funded by a NERC PhD studentship grant number NE/I52797/X, the 2012 fieldwork was funded by the NERC Collaborative Gearing Scheme grant number CGS-76 and the SI analysis was funded by the NERC Life Sciences Mass Spectrometry Facility grant number EK204-14/12.

\section{LITERATURE CITED}

Araújo MS, Bolnick DI, Layman CA (2011) The ecological causes of individual specialisation. Ecol Lett 14:948-958

Atkinson A, Siegel V, Pakhomov E, Rothery P (2004) Longterm decline in krill stock and increase in salps within the Southern Ocean. Nature 432:100-103

> Barlow KE, Croxall JP (2002) Seasonal and interannual variation in foraging range and habitat of macaroni penguins Eudyptes chrysolophus at South Georgia. Mar Ecol Prog Ser 232:291-304

Barquete V, Strauss V, Ryan PG (2013) Stable isotope turnover in blood and claws: a case study in captive African Penguins. J Exp Mar Biol Ecol 448:121-127

Bearhop S, Phillips RA, McGill R, Cherel Y, Dawson DA, Croxall JP (2006) Stable isotopes indicate sex-specific and long-term individual foraging specialisation in diving seabirds. Mar Ecol Prog Ser 311:157-164

> Behrenfeld MJ, O' Malley RT, Siegel DA, McClain CR and others (2006) Climate-driven trends in contemporary ocean productivity. Nature 444:752-755

Blain S, Treguer P, Belviso S, Bucciarelli E and others (2001) A biogeochemical study of the island mass effect in the context of the iron hypothesis: Kerguelen Islands, Southern Ocean. Deep-Sea Res I 48:163-187

Bolnick DI, Amarasekare P, Araújo MS, Bürger R and others (2011) Why intraspecific trait variation matters in community ecology. Trends Ecol Evol 26:183-192

> Bost CA, Charrassin JB, Clerquin Y, Ropert-Coudert Y, Le Maho Y (2004) Exploitation of distant marginal ice zones by king penguins during winter. Mar Ecol Prog Ser 283: 293-297

Brooke M de L (2004) The food consumption of the world's seabirds. Proc R Soc B (Suppl) 271:S246-S248

Brown CR (1986) Feather growth, mass loss and duration of moult in macaroni and rock-hopper penguins. Ostrich 
57:180-184

Burnham KP, Anderson DR (2002) Model selection and multi-model inference: a practical information-theoretic approach. Springer, New York, NY

Ceia FR, Ramos JA (2015) Individual specialization in the foraging and feeding strategies of seabirds: a review. Mar Biol 162:1923-1938

- Charrassin JB, Bost CA (2001) Utilisation of the oceanic habitat by king penguins over the annual cycle. Mar Ecol Prog Ser 221:285-298

Cherel Y, Hobson KA (2007) Geographical variation in carbon stable isotope signatures of marine predators: a tool to investigate their foraging areas in the Southern Ocean. Mar Ecol Prog Ser 329:281-287

> Cherel Y, Hobson KA, Bailleul F, Groscolas R (2005) Nutrition, physiology, and stable isotopes: new information. Ecology 86:2881-2888

> Cherel Y, Hobson KA, Guinet C, Vanpe C (2007) Stable isotopes document seasonal changes in trophic niches and winter foraging individual specialization in diving predators from the Southern Ocean. J Anim Ecol 76:826-836

> Crossin GT, Trathan PN, Phillips RA, Dawson A, Le Bouard F, Williams TD (2010) A carryover effect of migration underlies individual variation in reproductive readiness and extreme egg size dimorphism in macaroni penguins. Am Nat 176:357-366

> Croxall JP, Reid K, Prince PA (1999) Diet, provisioning and productivity responses of marine predators to differences in availability of Antarctic krill. Mar Ecol Prog Ser 177: 115-131

> Dalerum F, Angerbjörn A (2005) Resolving temporal variation in vertebrate diets using naturally occurring stable isotopes. Oecologia 144:647-658

Darimont CT, Paquet PC, Reimchen TE (2009) Landscape heterogeneity and marine subsidy generate extensive intrapopulation niche diversity in a large terrestrial vertebrate. J Anim Ecol 78:126-133

> Dunton KH, Weingartner T, Carmack EC (2006) The nearshore western Beaufort Sea ecosystem: circulation and importance of terrestrial carbon in Arctic coastal food webs. Prog Oceanogr 71:362-378

Evangelista C, Boiche A, Lecerf A, Cucherousset J (2014) Ecological opportunities and intraspecific competition alter trophic niche specialization in an opportunistic stream predator. J Anim Ecol 83:1025-1034

Fielding S, Watkins JL, Trathan PN, Enderlein P and others (2014) Interannual variability in Antarctic krill (Euphausia superba) density at South Georgia, Southern Ocean: 1997-2013. ICES J Mar Sci 71:2578-2588

Folch J, Lees M, Sloane-Stanley GH (1957) A simple method for the isolation and purification of total lipids from animal tissues. J Biol Chem 226:497-509

Fox J, Weisberg S, Adler D, Bates D and others (2015) Package 'car' version 2.0-25. https://cran.r-project.org/web/ packages/car/index.html

Fraley C, Raftery AE, Scrucca L (2014) Package 'mclust' version 4.3. https://cran.r-project.org/web/packages/mclust/ index.html

France RL (1995) Carbon-13 enrichment in the benthic compared to planktonic algae: foodweb implications. Mar Ecol Prog Ser 124:307-312

Frazer TK, Ross RM, Quetin LB, Montoya JP (1997) Turnover of carbon and nitrogen during growth of larval krill, Euphausia superba Dana: a stable isotope approach. J Exp Mar Biol Ecol 212:259-275
Gauthier-Clerc M, Le Maho Y, Gendner JP, Durant J, Handrich Y (2001) State-dependent decisions in long-term fasting king penguins, Aptenodytes patagonicus, during courtship and incubation. Anim Behav 62:661-669

González-Solís J, Croxall JP, Wood AG (2000) Foraging partitioning between giant petrels Macronectes spp. and its relationship with breeding population changes at Bird Island, South Georgia. Mar Ecol Prog Ser 204: 279-288

> Green JA, Boyd IL, Woakes AJ, Warren NL, Butler PJ (2009) Evaluating the prudence of parents: daily energy expenditure throughout the annual cycle of a free-ranging bird, the macaroni penguin Eudyptes chrysolophus. J Avian Biol 40:529-538

> Herrera MLG, Korine C, Fleming TH, Arad Z (2008) Dietary implications of intrapopulation variation in nitrogen isotope composition of an old world fruit bat. J Mammal 89: 1184-1190

Hewitt RP, Demer DA, Emery JH (2003) An 8-year cycle in krill biomass density inferred from acoustic surveys conducted in the vicinity of the South Shetland Islands during the austral summers of 1991-1992 through 20012002. Aquat Living Resour 16:205-213

Hobson KA, Piatt JFJ, Pitocchelli J (1994) Using stable isotopes to determine seabird trophic relationships. J Anim Ecol 63:786-798

Hoefs J (1997) Stable isotope geochemistry. SpringerVerlag, Berlin

Hughes AR, Inouye BD, Johnson MTJ, Underwood N, Vellend $M$ (2008) Ecological consequences of genetic diversity. Ecol Lett 11:609-623

Kernaléguen L, Arnould JPY, Guinet C, Cherel Y (2015) Determinants of individual foraging specialisation in large marine vertebrates, the Antarctic and subantarctic fur seals. J Anim Ecol 84:1081-1091

Koslov AN, Shust KV, Zemsky AV (1991) Seasonal and interannual variability in the distribution of Electrona carlsbergi in the Southern Polar Front area. In: Selected scientific papers (SC-CAMLR-SSP/7). Committee Conservation Antarctic Living Resources, Hobart, p 337-367

> Layman CA, Quattrochi JP, Peyer CM, Allgeier JE (2007) Niche width collapse in a resilient top predator following ecosystem fragmentation. Ecol Lett 10:937-944

Lemons GE, Eguchi T, Lyona BN, LeRoux R, Seminoff JA (2012) Effects of blood anticoagulants on stable isotope values of sea turtle blood tissue. Aquat Biol 14:201-206

Lowther AD, Lydersen C, Biuw M, de Bruyn PJN, Hofmeyr GJG, Kovacs KM (2014) Post-breeding at-sea movements of three central-place foragers in relation to submesoscale fronts in the Southern Ocean around Bouvetøya. Antarct Sci 12:1-12

Meredith MP, Watkins JL, Murphy EJ, Cunningham NJ and others (2003) An anticyclonic circulation above the Northwest Georgia Rise, Southern Ocean. Geophys Res Lett 30:1-5

> Pace ML, Cole JJ, Carpenter SR, Kitchell JF (1999) Trophic cascades revealed in diverse ecosystems. Trends Ecol Evol 14:483-488

Phillips RA, McGill RAR, Dawson DA, Bearhop S (2011) Sexual segregation in distribution, diet and trophic level of seabirds: insights from stable isotope analysis. Mar Biol 158:2199-2208

R Development Core Team (2014) R: a language and environment for statistical computing. R Foundation for Statistical Computing, Vienna 
Ratcliffe N, Crofts S, Brown RM, Baylis AMM and others (2014) Love thy neighbour or opposites attract? Patterns of spatial segregation and association among crested penguin populations during winter. J Biogeogr 41: 1183-1192

Raya Rey A, Trathan P, Pütz K, Schiavini A (2007) Effect of oceanographic conditions on the winter movements of rockhopper penguins Eudyptes chrysocome chrysocome from Staten Island, Argentina. Mar Ecol Prog Ser 330: 285-295

Rogerson PA (2001) Statistical methods for geography. Sage, London

Samour HJ, Jones DM, Pugsley S, Fitzgerald AK (1983) Blood sampling technique in penguins (Sphenisciformes). Vet Rec 113:340

Schmidt K, Atkinson A, Stübing D, McClelland JW, Montoya JP, Voss M (2003) Trophic relationships among Southern Ocean copepods and krill: some uses and limitations of a stable isotope approach. Limnol Oceanogr 48: 277-289

Schoeninger MJ, DeNiro MJ (1984) Nitrogen and carbon isotopic composition of bone collagen from marine and terrestrial animals. Geochim Cosmochim Acta 48:625-639

Stowasser G, Atkinson A, McGill RAR, Phillips RA, Collins MA, Pond DW (2012) Food web dynamics in the Scotia Sea in summer: a stable isotope study. Deep-Sea Res II 59-60:208-221

Sumner MD, Luque S (2013) trip: spatial analysis of animal track data 1.1-21. https://cran.r-project.org/web/packages/ trip/index.html

Sumner MD, Wotherspoon S (2013) tripEstimation: metropolis sampler and supporting functions for estimating animal movement from archival tags and satellite fixes, version 0.0-41. https://cran.r-project.org/web/packages/ tripEstimation/index.html

Swartzman G, Huang C, Kaluzny S (1992) Spatial analysis of

Editorial responsibility: Susanne Schüller,

Oldendorf/Luhe, Germany
Bering Sea groundfish survey data using generalized additive models. Can J Fish Aquat Sci 49:1366-1378

Thiebot JB, Cherel Y, Trathan PN, Bost CA (2011) Inter-population segregation in the wintering areas of macaroni penguins. Mar Ecol Prog Ser 421:279-290

Thiebot JB, Cherel Y, Acqueberge M, Prudor A, Trathan PN, Bost CA (2014) Adjustment of pre-moult foraging strategies in macaroni penguins Eudyptes chrysolophus according to locality, sex and breeding status. Ibis 156 : 511-522

Thorpe SE, Heywood KJ, Brandon MA, Stevens DP (2002) Variability of the southern Antarctic Circumpolar Current front north of South Georgia. J Mar Syst 37:87-105

Trull TW, Armand L (2001) Insights into Southern Ocean carbon export from the $\delta^{13} \mathrm{C}$ of particles and dissolved inorganic carbon during the SOIREE iron release experiment. Deep-Sea Res II 48:2655-2680

Waluda CM, Collins MA, Black AD, Staniland IJ, Trathan PN (2010) Linking predator and prey behaviour: contrasts between Antarctic fur seals and macaroni penguins at South Georgia. Mar Biol 157:99-112

- Waluda CM, Hill SL, Peat HJ, Trathan PN (2012) Diet variability and reproductive performance of macaroni penguins Eudyptes chrysolophus at Bird Island, South Georgia. Mar Ecol Prog Ser 466:261-274

Weimerskirch H, Cherel Y, Delord K, Jaeger A, Patrick SC, Riotte-Lambert L (2014) Lifetime foraging patterns of the wandering albatross: life on the move! J Exp Mar Biol Ecol 450:68-78

Williams TD (1995) The penguins: Spheniscidae. Oxford University Press, Oxford

Williams TD, Croxall JP (1991) Annual variation in breeding biology of macaroni penguins, Eudyptes chrysolophus, at Bird Island, South Georgia. J Zool Lond 223:189-202

Zuur A, Ieno EN, Smith GM (2007) Analysing ecological data. Springer Science \& Business Media, New York, NY

Submitted: July 16, 2015; Accepted: January 21, 2016

Proofs received from author(s): April 14, 2016 